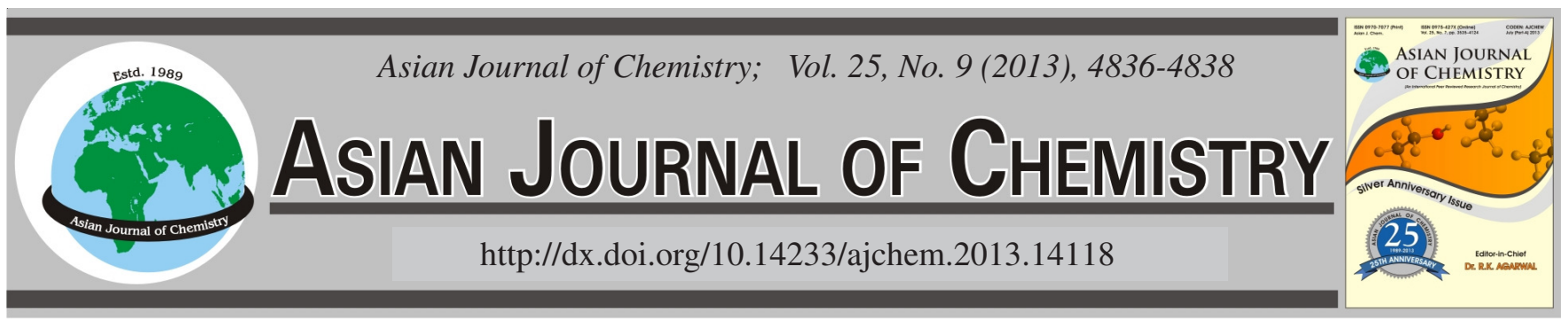

\title{
Synthesis and Antimicrobial Activities on Staphylicoccus aureus of Miscellaneous Atomic Curcumin Derivatives
}

\author{
Huasen Wang, Beilei Jiang and Qiyong Huai*
}

Marine College of Shandong University, Weihai 264209, P.R. China

*Corresponding author: E-mail: huaiqy01@163.com

(Received: 27 May 2012;

Accepted: 8 March 2013)

AJC-13084

Miscellaneous atomic curcumin derivatives were synthesized with biotin, lipolic acid, isonicotinic acid and curcumin, employing the acylchloride method. Their chemical structures were confirmed by IR, MS and ${ }^{1} \mathrm{H}$ NMR spectroscopy. The antimicrobial activities of these new compounds and curcumin were explored with Staphylicoccus aureus under the same conditions. The result showed that the antimicrobial activity of these new compounds were better than curcumin especially the MIC of lipolic curcumin was $2.5 \mathrm{mg} / \mathrm{mL}$, which was 4 times better than curcumin.

Key Words: Biotinylated curcumin, Lipolate curcumin, Isonicotinate curcumin, Staphylicoccus aureus, Antimicrobial activities.

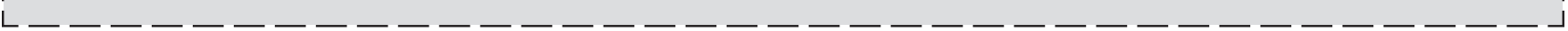

\section{INTRODUCTION}

Curcumin is a $\beta$-diketone constituent of the turmerichat is obtained from the powdered root of Curcumaonga Linn. Curcumin has been used by traditional medicine for liver disease (jaundice), indigestion, urinary tract diseases, rheumatoid arthritis and insect bites. This phytochemical has also been demonstrated to possess both anticancer and antiangiogenic properties ${ }^{1}$. The studies showed that the phenolic groups and the active methylene in curcumin were connected with biomolecular potential target for antibacterial activity and curcumin derivatives containing heteroatoms had stronger efficancy ${ }^{2,3}$. Biotin (vitamin $\mathrm{H}$ ), as a pure natural product, can help treat diabetes in addition to biotin deficiency and according to a variety of animal experiments, even given excessive biotin, there were no side effects ${ }^{4}$. The lipoic acid has much better antioxidant activity compared with general antioxidants and has been used for the treatment of diabetic neuropathy in Germany for decades ${ }^{5}$. Nicotinic is used as clinical drugs to regulate dyslipidemia ${ }^{6}$ and isonicotinic acid as its isomers, there is great significance to explore its antimicrobial activities. So we decided to use biotin, lipoic acid, isonicotinic acid and curcumin to synthesize miscellaneous atomic curcumin. And the antimicrobial activities of these new chemical compounds and curcumin were explored with Staphylicoccus aureus under the same conditions in order to provide a theoretical basis for the further expansion of the natural products in the aspect of medicinal value.

\section{EXPERIMENTAL}

The miscellaneous atomic curcumin derivaives were synthesized with biotin, lipolic acid, isonicotinic acid and curcumin employing the acyl chloride method (Schemes I-III).

Screening for antimicrobial activity ${ }^{\mathbf{7 8}}$ : Activate Staphylococcus aureus at the optimum temperature for $2 \mathrm{~h}$ then transfer to the freshly prepared activation medium. After shaking for $24 \mathrm{~h}$, dilute the bacter solution into $10^{8} \mathrm{cfu} / \mathrm{mL}$. Antimicrobial activity was tested by the agar-well diffusion method. Different concentrations of the products $(0.25-100$ $\mathrm{mg} / \mathrm{mL}$ ) were dissolved in ethanol. The antibacterial assay plates were incubated at $37^{\circ} \mathrm{C}$ for $24 \mathrm{~h}$. The standard discs $(6$ $\mathrm{mm}$ diameter) of the products and sterile saline served as a negative control, while ethanol was used as a positive control. The diameter of the zones of inhibition around each of the discs was taken as measure of the antimicrobial activity. Each experiment was carried out in triplicate and the mean diameter of the inhibition zone was recorded (Tables 1 and 2).

Minimum inhibitory concentration (MIC): Transfer 0.1 $\mathrm{mL}$ of $108 \mathrm{cfu} / \mathrm{mL}$ Staphylococcus aureus to each petri dish and applied to each petri dish with $0.625-200 \mathrm{mg} / \mathrm{mL}$ miscellaneous atomic curcumin and curcumin. The MIC values were interpreted as the lowest concentration of the sample, which showed clear fluid with no development of turbidity. All tests were performed in triplicate (Tables 1 and 2). 

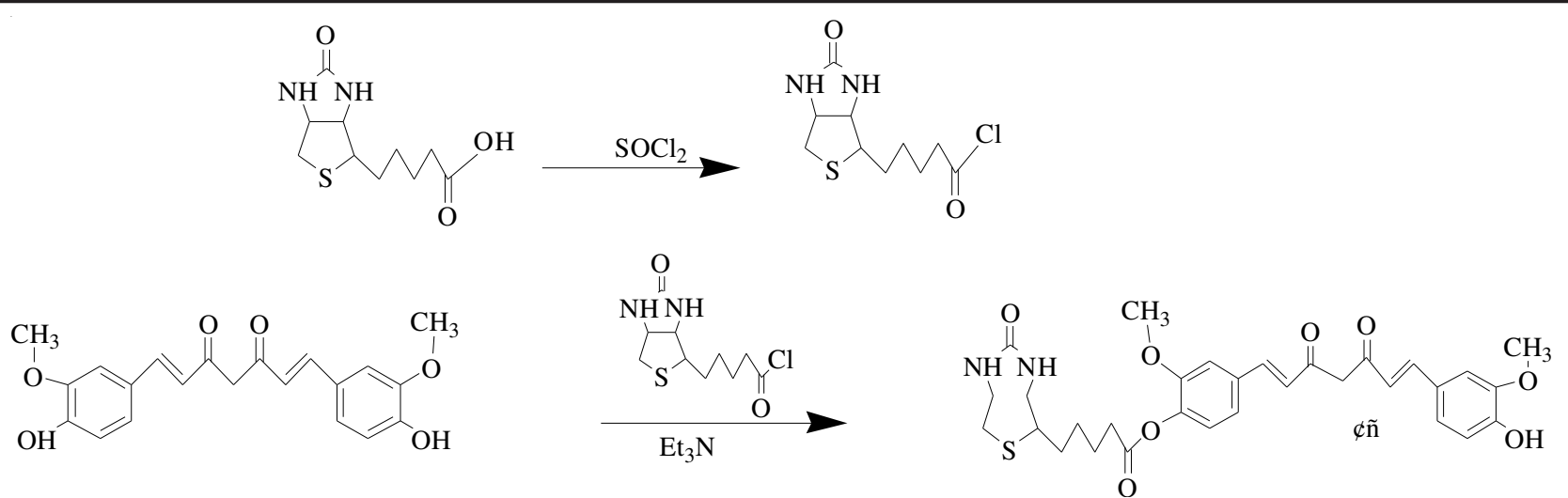

Scheme-I: Synthesis of biotinylated curcumin. Reagents and conditions: (a) biotin $1 \mathrm{mmol}, \mathrm{SOCl}_{2} 4 \mathrm{~mL}$, reflux, $40{ }^{\circ} \mathrm{C}$, oil bath for $7 \mathrm{~h}$. (b) biotin chloride, curcumin $0.2 \mathrm{mmol}, \mathrm{Et}_{3} \mathrm{~N} 2 \mathrm{~mL}, \mathrm{~N}_{2}, 37^{\circ} \mathrm{C}$, reflux, for $24 \mathrm{~h}$<smiles>CCC(CCCC(=O)O)SS(C)(C)C(=O)O</smiles>

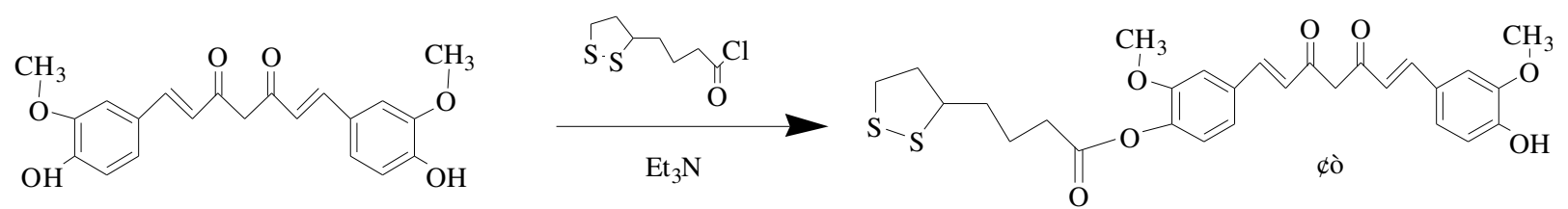

Scheme-II: Synthesis of lipolate curcumin. Reagents and conditions: (a) alpha lipoic acid $1 \mathrm{mmol}, \mathrm{SOCl}_{2} 4 \mathrm{~mL}$, reflux, $40{ }^{\circ} \mathrm{C}$, oil bath for $7 \mathrm{~h}$. (b) curcumin $0.2 \mathrm{mmol}, \mathrm{Et}_{3} \mathrm{~N} 2 \mathrm{~mL}, \mathrm{~N}_{2}, 37^{\circ} \mathrm{C}$, reflux, for $24 \mathrm{~h}$<smiles>O=C(O)c1ccncc1</smiles><smiles>O=C(Cl)c1ccncc1</smiles><smiles>COc1cc(/C=C/C(=O)CC(=O)/C=C/c2ccc(O)c(OC)c2)ccc1O</smiles><smiles>CCN(CC)CCNCCCN</smiles>

Scheme-III: Synthesis of isonicotinate curcumin. Reagents and conditions: (a) Isonicotinic acid $24.4 \mathrm{mmol}, \mathrm{SOCl}_{2} 20 \mathrm{~mL}$, DMF $0.2 \mathrm{~mL}$, reflux, ice bath then heated to $77^{\circ} \mathrm{C}$ oil bath for $4 \mathrm{~h}$. (b) curcumin $5 \mathrm{mmol}, \mathrm{Et}_{3} \mathrm{~N} 8 \mathrm{~mL}, \mathrm{~N}_{2}, 37^{\circ} \mathrm{C}$, reflux, for $12 \mathrm{~h}$

\section{RESULTS AND DISCUSSION}

From the date, it is observed that the MICs of lipolate curcumin, biotinylated curcumin, isonicotinate curcumin and curcumin were $2.5,5,5$ and $10 \mathrm{mg} / \mathrm{mL}$. The result showed that the antimicrobial activity of lipolate curcumin was at least
4 times as good as curcumin. And curcumin derivatives modified with sulphur atoms had higher antibacterial activity than that with nitrogen atoms. Because Staphylococcus aureus is harm to body and curcumin derivatives modfided with heteroatoms have strong inhibitory effect, it is of great significance in clinical applications.

\begin{tabular}{|c|c|c|c|c|c|c|}
\hline \multicolumn{7}{|c|}{$\begin{array}{c}\text { TABLE-1 } \\
\text { MIC OF THE PRODUCTS ON Staphylicoccus aureus (CULTURED } 24 \text { h AT } 37^{\circ} \mathrm{C} \text { ) }\end{array}$} \\
\hline $\begin{array}{l}\text { Treatment } \\
(\mathrm{mg} / \mathrm{mL})\end{array}$ & Curcumin & Lipolate curcumin & $\begin{array}{l}\text { Biotinylated } \\
\text { curcumin }\end{array}$ & $\begin{array}{l}\text { Isonicotinate } \\
\text { curcumin }\end{array}$ & $\begin{array}{l}\text { Negative control } \\
\text { (Sterile saline) }\end{array}$ & $\begin{array}{l}\text { Positive control } \\
\text { (ethanol) }\end{array}$ \\
\hline 200 & - & - & - & - & +++++ & ++ \\
\hline 100 & - & - & - & - & +++++ & ++ \\
\hline 10 & - & - & - & - & +++++ & ++ \\
\hline 5 & +++++ & - & - & - & +++++ & ++ \\
\hline 2.5 & +++++ & - & ++ & +++ & +++++ & ++ \\
\hline 1.25 & +++++ & +++ & +++++ & +++++ & +++++ & ++ \\
\hline 0.625 & +++++ & +++++ & +++++ & +++++ & +++++ & ++ \\
\hline
\end{tabular}


TABLE-2

INHIBITION ZONE OF THE PRODUCTS ON Staphylicoccus aureus (CULTURED $24 \mathrm{~h} \mathrm{AT} 37^{\circ} \mathrm{C}$ )

\begin{tabular}{lcccc}
\hline \multicolumn{1}{c}{ Treatment } & Curcumin & Lipolate curcumin & Biotinylated curcumin & Isonicotinate curcumin \\
\hline $100 \mathrm{mg} / \mathrm{mL}$ & 12 & 18 & 16 & 16 \\
$10 \mathrm{mg} / \mathrm{mL}$ & 9 & 18 & 12 & 12 \\
$5 \mathrm{mg} / \mathrm{mL}$ & 7 & 13 & 10 & 9 \\
$2.5 \mathrm{mg} / \mathrm{mL}$ & 7 & 10 & 8 & 8 \\
Positive control (ethanol) & 7 & 7 & 7 & 7 \\
Negative control (sterile saline) & 6 & 6 & 6 & 6 \\
\hline
\end{tabular}

\section{Conclusion}

Curcumin derivatives in particular modefied with heteroatoms will expand the medicinal value of curcumin and provide theoretical basis for the mechanism of the antibacterial activity.

\section{ACKNOWLEDGEMENTS}

This research was supported by the Natural Science Foundation of Shandong Province (No. ZR2010BM021) and The Student Research Training Program of Shandong University at Weihai (No. A11034).

\section{REFERENCES}

1. A. Foryst-Ludwig, M. Neumann, W. Schneider-Brachert and M. Naumann, Biochem. Biophys. Res. Commun., 16, 1065 (2004).
2. Y. Aratanechemugei, I.T. Komira, H. Moteki, H. Katsuzaki, K. Imai and H. Hibasami, Int. J. Mol. Med., 9, 481 (2002).

3. S. Mishra, K. Karmodiya, N. Surolia and A. Surolia, Bioorg. Med. Chem., 16, 2894 (2008).

4. X. Li and J. Chu, Chin. J. Antibiot., 33, 6 (2009).

5. G.P. Biewenga, G.R. Haenen and A. Bast, Gen. Pharmacol. J., 29, 315 (1997).

6. R.A. Hammoud, C.S. Vaccari, S.H. Nagamia and B.V. Khan, Vasc. Health Risk Manag., 3, 937 (2007).

7. Yan Cenhu, Biofunctionalization of Polylactide-Polyethylene Glycol (PLA-PEG) Nanoparticles for Targeting to Brain Glioma, Master's Dissertations of Tianjin University, pp. 25-34 (2007).

8. K.-J. Kim, H.-H. Yu, J.-D. Cha, S.-J. Seo, N.-Y. Choi and Y.-O. You, Phytother. Res., 19, 599 (2005). 